\title{
BIMBINGAN BERTANAM BAWANG PUTIH DALAM POLIBAG UNTUK MENINGKATKAN KETAHANAN PANGAN KELUARGA DI SAAT PANDEMI CORONA
}

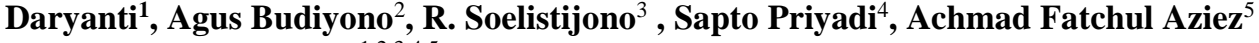 \\ 1,2,3,4,5 Universitas Tunas Pembangunan \\ Email Korespondensi: dyanti_utp@yahoo.co.id
}

\begin{abstract}
Abstrak
Bawang putih banyak dibutuhkan masyarakat di Indonesia. Kebutuhan bawang putih tinggi tetapi produksi dalam negeri tidak mencukupi sehingga selalu impor. Harga bawang putih di pasaran di saat-saat tertentu melonjak tinggi. Untuk itu perlu upaya meningkatkan kemampuan masyarakat dalam memenuhi kebutuhan bawang putih dengan cara menanam sendiri bawang putih di halaman rumah. Kegiatan pengabdian masyarakat ini bertujuan memberikan penyuluhan dan pelatihan bertanam bawang putih dalam polibag. Kegiatan pengabdian dilaksanakan di Sorogenen, Kelurahan Jagalan, Surakarta pada bulan Mei - Agustus 2020. Peserta terdiri dari ibu-ibu pengurus Pokja III PKK Kelurahan Jagalan. Materi penyuluhan tentang mengenal tanaman bawang putih, manfaat bawang putih bagi kesehatan dan teori tentang cara bertanam bawang putih dalam polibag. Kegiatan praktek meliputi cara penyiapan media, cara memilih bibit yang baik, cara menanam, pemeliharaan dan panen. Kepada peserta diberikan paket berupa bahan media tanam, polibag, sprayer, benih bawang putih varietas Lumbu Putih (varietas dataran rendah) untuk ditanam di rumah masing-masing. Tim pengabdian melakukan monitoring perkembangan tanaman peserta. Dari hasil kegiatan ini disimpulkan: ada peningkatan pengetahuan peserta tentang bawang putih dan manfaatnya untuk kesehatan, peserta bisa melakukan penyiapan media, penanaman, pemeliharaan dengan benar. Ibu-ibu mampu bertanam bawang putih dalam polibag di rumah masing-masing dengan baik. Umbi bawang putih hasil panen para peserta berukuran kecil (diameter umbi 1-2 cm) tidak membentuk siung atau berupa bawang tunggal tetapi mempunyai aroma yang lebih tajam dibanding bawang impor.
\end{abstract}

Kata kunci: bawang putih, polibag, konsumsi keluarga

\begin{abstract}
Garlic is much needed by people in Indonesia. The need for garlic is high but domestic production is insufficient so it is always imported. The price of garlic in the market at certain times soaring highs. For this reason, it is necessary to increase the community's ability to meet the needs of garlic by growing garlic by themselves in the yard. This community service activity aims to provide counseling and training on cultivating garlic in polybags. The community service activities were held in Sorogenen, Jagalan, Surakarta in May - August 2020. Participants consisted of women who are members of Pokja III PKK, Jagalan sub-district. Extension materials on knowing garlic plants, the benefits of garlic for health and theories on how to grow garlic in polybags. Practical activities include how to prepare the media, how to choose good seeds, how to plant, maintenance and harvest. Participants were given packages in the form of planting media, polybags, sprayer, garlic seeds of Lumbu Putih variety (lowland variety) to be planted in their yard homes. The service team monitoring of development of the participants' plants. From the results of this activity it was concluded: there was an increase in the participants' knowledge about garlic and its benefits for health, participants could carry out media preparation, planting and maintenance properly. The housewife are able to grow garlic in polybags in their yard homes. The garlic bulbs that were harvested by the participants were small (1-2 cm in diameter) and did not form cloves or single onions but had a sharper flavour than imported onions.
\end{abstract}

Key words: garlic, polybag, family consumption

\section{PENDAHULUAN}

Bawang putih banyak dibutuhkan masyarakat di Indonesia sebagai bumbu masak sehari-hari. Selain sebagai bumbu masak, bawang putih mempunyai banyak manfaat untuk kesehatan yaitu sebagai anti bakteri, anti jamur, antioksidan, anti protozoa dan lain-lain. Bawang putih juga dipercaya mempunyai efek protektif bagi system kardiovaskular dan 
mempunyai potensi sebagai anti tumor. Bawang putih juga digunakan untuk mengatasi infeksi saluran cerna, mencegah infeksi luka, mengobati flu, sakit kepala, sakit tenggorokan.

Bawang putih kaya kandungan sulfur, senyawa ini yang bertanggungjawab atas berbagai manfaat terapeutik bawang putih dan memberi bau khas bawang putih . Diallyl thiosulfinate (allicin ) merupakan senyawa sulfur dalam bawang putih yang mempunyai manfaat antibakteri, anti jamur dan anti virus yang paling besar. Allicin baru akan muncul dari metabolisme alliin oleh enzim allinase apabila bawang putih mengalami kerusakan sel karena dipotong atau ditumbuk . Allicin bisa menghambat sintesis RNA bakteri, menghambat sintesis DNA bakteri secara parsial . Allicin memiliki sifat yang kurang stabil, oleh karena itu, dalam beberapa jam dalam suhu ruangan, akan kembali mengalami metabolisme menjadi vynilthidiines atau dyallildisulfide atau yang disebut ajoene. Senyawa sulfur ini memiliki aktivitas antibakteri yang bekerja dengan mekanisme yang sama dengan allicin, namun memiliki potensi yang lebih kecil daripada allicin (Deresse D, 2011).

Kebutuhan bawang putih di Indonesia tinggi akan tetapi produksi dalam negeri tidak mampu mencukupi sehingga selalu impor. Pada tahun 2016 produksi bawang putih di Indonesia 21.150 ton, sedangkan pada tahun tersebut kebutuhannya sebesar 455.284 ton sehingga untuk mencukupi kebutuhan dilakukan impor 444.300 ton (BPS, 2017). Ketergantungan yang tinggi terhadap bawang putih impor ini menyebabkan pada waktuwaktu tertentu, misalnya di saat menjelang hari raya, demikian pula di saat awal adanya wabah Corona karena adanya hambatan impor, harga bawang putih melonjak tinggi. Di saat harga bawang putih melonjak tinggi tentu hal ini menambah beban pengeluaran rumah tangga.

Untuk itu perlu ada upaya meningkatkan kemampuan masyarakat dalam memenuhi kebutuhan bawang putih setidaknya untuk konsumsi keluarga. Bawang putih tidak selalu harus dibudidayakan di dataran tinggi dan di lahan yang luas. Di dataran rendah dan di perkotaan yang umumnya lahan sangat terbatas, tetap bisa membudidayakan bawang putih (Anonim, 1993) yaitu dengan menanamnya dalam pot, polibag atau wadah bekas lainnya. Oleh karena itu pada kegiatan pengabdian masyarakat ini diberikan bimbingan dan praktek cara bertanam bawang putih dalam polibag.

\section{METODE}

Kegiatan pengabdian masyarakat ini dilaksanakan di Sorogenen, Kelurahan Jagalan, Kota Surakarta pada bulan Mei - Agustus 2020. Bahan yang digunakan terdiri dari bahan media tanam (tanah, arang sekam, pupuk kandang), benih bawang putih varietas Lumbu Putih dari Kecamatan Playen Gunung Kidul. Alat terdiri dari sekop, cetok, sprayer, polibag. Kegiatan dilaksanakan dengan metode penyuluhan dilanjutkan praktek serta monitoring kegiatan. Peserta terdiri dari ibu-ibu pengurus Pokja III PKK Kelurahan Jagalan (10 orang). Dalam pelaksanaan kegiatan pengabdian ini dibantu oleh 1 orang mahasiswa Fakultas Pertanian UTP. Kegiatan dilaksanakan dengan menerapkan protokol kesehatan untuk mencegah bahaya Covid-19 yaitu peserta dibatasi jumlahnya, selalu memakai masker, mencuci tangan sebelum dan sesudah kegiatan, menjaga jarak antar peserta.

\section{HASIL DAN PEMBAHASAN}

Pada pelaksanaan kegiatan, sebelum dan sesudah penyuluhan dibagikan angket untuk diisi oleh peserta yang bertujuan untuk mengetahui tingkat pengetahuan peserta tentang materi yang diberikan yaitu tentang bawang putih dan cara bertanamnya dalam polibag. Pada kegiatan praktek, semua peserta melakukan praktek langsung mulai dari cara memilih benih, penyiapan media tanam, cara penanaman, pemeliharaan dan gambaran cara panen dan pasca panen. Di akhir kegiatan praktek, kepada peserta diberikan paket yang berisi benih bawang 
putih, bahan media tanam (pupuk organik, arang sekam), polibag dan sprayer. Para peserta selanjutnya melakukan penanaman bawang putih di rumah masing-masing. Tim pengabdian melakukan monitoring dan evaluasi untuk mengetahui perkembangan pertumbuhan bawang putih yang ditanam oleh ibu-ibu peserta.
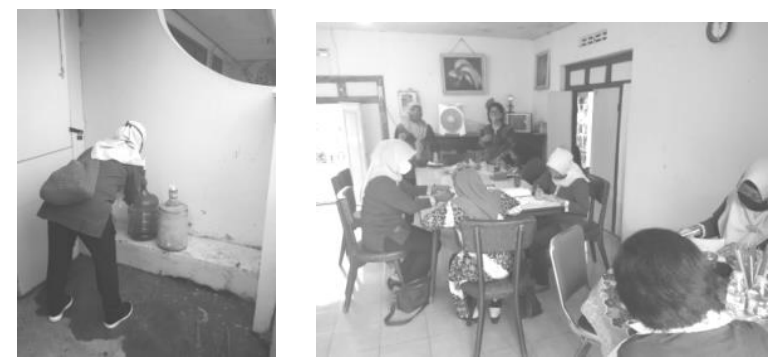

Gambar 1. Pelaksanaan kegiatan pengabdian dengan menerapkan protokol kesehatan

Pada penyampaian materi dijelaskan tentang kedudukan bawang putih sebagai bumbu masak yang penting, tetapi ternyata sebagian besar berasal dari impor sehingga harga bawang putih di saat-saat tertentu melonjak tinggi. Untuk itu perlu upaya bertanam bawang putih di halaman rumah. Meskipun halaman sempit, bisa bertanam menggunakan polibag. Kepada ibu-ibu dijelaskan pula tentang manfaat bawang putih untuk kesehatan.

Peserta cukup antusias dalam mengikuti tahap penyuluhan, terbukti dari adanya pertanyaan-pertanyaan yang diajukan para peserta. Pengetahuan yang diberikan tentang bawang putih bisa dipahami dengan baik oleh peserta, hal ini terlihat dari hasil jawaban peserta pada angket yang diberikan. Ada peningkatan pengetahuan peserta sesudah penyuluhan dibandingkan sebelumnya. Dari hasil jawaban peserta diketahui sebagian besar peserta $(90 \%)$ sudah mengetahui bahwa bawang putih yang beredar di pasaran adalah bawang impor dari Tiongkok, sudah mengetahui beberapa manfaat bawang putih untuk kesehatan. Pengetahuan tentang manfaat bawang putih untuk kesehatan ini semakin bertambah setelah diberikan penjelasan melalui penyuluhan. Dari hasil angket diketahui pula bahwa semua peserta belum mengetahui tentang jenis-jenis bawang putih lokal di Indonesia dan belum mengetahui cara bertanam bawang putih dengan menggunakan polibag, namun setelah diberikan penyuluhan, semua peserta menjadi paham tentang hal tersebut.

Pada kegiatan praktek, diawali dengan pengenalan alat dan bahan yang dibutuhkan, dilanjutkan dengan praktek. Hal pertama yang perlu diperhatikan dalam menanam bawang putih yaitu saat tanam, hendaknya dilakukan pada musim kemarau (sekitar bulan Juni-Juli) karena apabila ditanam dimusim penghujan, tanaman rawan busuk dan kurang sinar matahari.

Kepada peserta dijelaskan ciri-ciri benih yang baik yaitu umbi padat atau berisi penuh dan keras, siung berpenampilan licin tegar, tidak kisut, tunas terlihat segar jika siung dipatahkan, berat siung sekitar 1,5-3 gram yang merupakan ukuran normal, bebas dari hama dan penyakit. Kegiatan dilanjutkan dengan penyiapan media tanam. Media tanam berupa campuran tanah, arang sekam dan pupuk kompos/pupuk kandang dengan perbandingan 1:1:1. Media dimasukkan ke dalam polibag ukuran 30 dan kemudian disiram air secukupnya saja. Umbi bawang dipisahkan siung-siungnya selanjutnya siung ditanam (4-5 siung per polibag) dengan ujung runcing menghadap ke atas tegak lurus, 1/3 bagian siung yaitu di bagian atas menyembul di permukaan tanah (Anonim, 1993). 


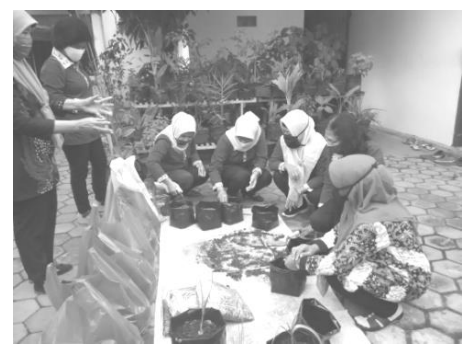

Gambar 2. Kegiatan praktek bertanam bawang putih dalam polibag

Perawatan tanaman bawang putih meliputi pemupukan, penyiraman, penyiangan, pengendalian hama dan penyakit dan pencahayaan. Selain pupuk organic yang dicampurkan pada media tanam, tanaman bawang putih perlu diberi pupuk untuk mencukupi kebutuhan nutrisi tanaman agar bisa membentuk umbi. Pada umur seminggu setelah tanam diberikan pupuk NPK sebanyak 5 butir per polibag. Selama pertumbuhan bisa ditambahkan pupuk organic cair yang disiramkan seminggu sekali. Untuk penyiraman tanaman dilakukan setiap hari sampai umur 2 bulan, selanjutnya bisa dikurangi 2-3 hari sekali dan sekitar 10 hari menjelang panen tidak perlu disiram.

Apabila dijumpai adanya gulma perlu dilakukan penyiangan. Untuk mencegah gangguan hama penyakit bisa dilakukan tindakan pencegahan dengan menggunakan pestisida nabati dari bahan-bahan yang mudah dijumpai di rumah misalnya dari bahan bawang putih, empon-empon. Tanaman bawang putih memerlukan sinar matahari penuh sehingga harus diletakkan pada lokasi yang tepat.

Bawang putih yang siap dipanen ditandai dengan perubahan tanaman menjadi kuning dan terlihat mulai layu. Umur panen bawang Lumbu Putih sekitar 90-120 hari setelah tanam (Anonim, 1993). Cara pemanenan bawang putih dilakukan dengan mencabut tanaman menggunakan tangan. Kemudian umbi hasil panen diikat dan dijemur hingga batangnya kering, membutuhkan waktu sekitar 1 minggu. Pada kegiatan praktek para peserta bisa melakukan semua tahapan dalam bertanam bawang putih di polibag dengan benar.

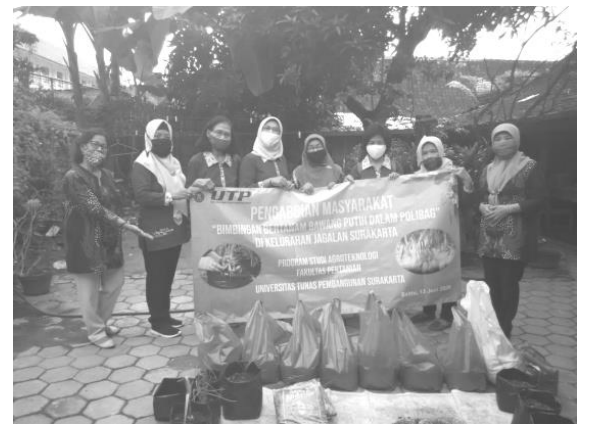

Gambar 3. Foto bersama setelah penyerahan paket bahan bertanam bawang putih

Kepada para peserta diberikan paket terdiri dari benih bawang putih varietas Lumbu Putih, polibag, bahan media tanam berupa arang sekam dan pupuk organik, sprayer. Selanjutnya para peserta melakukan penanaman bawang putih di rumah masing-masing dan Tim Pengabdian melakukan monitoring dan evaluasi perkembangan tanaman bawang putih yang ditanam ibu-ibu peserta dan memberikan solusi apabila terdapat kendala. Dari hasil monitoring diketahui ibu-ibu peserta bisa melakukan penanaman bawang putih dalam polibag dengan baik terbukti dari perkembangan tanaman yang subur dan terlihat hijau segar. 


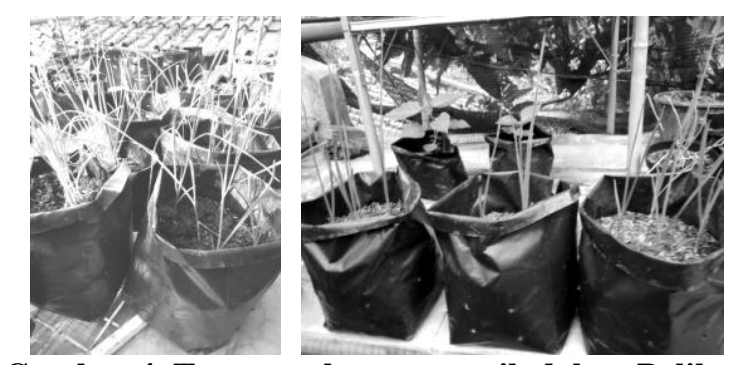

Gambar 4. Tanaman bawang putih dalam Polibag

Pada kegiatan ini oleh karena pertemuan harus dilaksanakan dalam waktu yang terbatas, kepada peserta juga diberikan booklet dan CD berisi video tentang materi yang diberikan pada pengabdian ini untuk mempermudah dalam mempelajari.

Tanaman bawang putih yang ditanam merupakan jenis yang memang cocok ditanam di dataran rendah yaitu varietas Lumbu Putih. Benih bawang ini berukuran kecil (diameter 2-3 $\mathrm{cm}$ ) jauh lebih kecil dibanding bawang di pasaran yang merupakan bawang impor dari Cina. Tetapi bawang Lumbu Putih mempunyai aroma yang tajam. Dari hasil monitoring, $80 \%$ peserta bisa melakukan penanaman bawang putih hingga berhasil panen, namun hasil umbi berukuran kecil (diameter 1-2 cm) dan tidak membentuk siung atau berbentuk bawang tunggal. Hal ini kemungkinan karena kurangnya nutrisi atau pupuk yang diberikan dan factor cahaya matahari yang kurang maksimal.

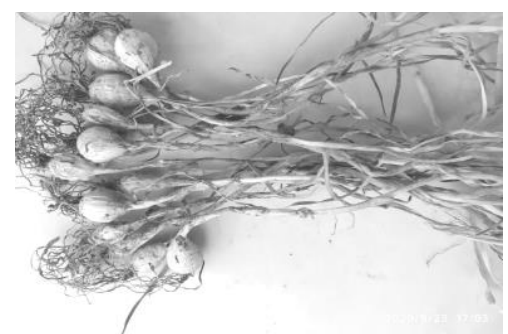

Gambar 5. Hasil panen bawang putih

Setelah mengikuti kegiatan ini diharapkan para peserta yang merupakan kader PKK, bisa menyebarluaskan pengetahuan dan keterampilaan yang diperoleh kepada ibu-ibu lainnya di lingkungan Kelurahan Jagalan.

\section{KESIMPULAN}

Dari kegiatan pengabdian ini dapat disimpulkan :

1. Materi yang disampaikan dalam kegiatan penyuluhan bisa diterima dengan baik oleh peserta. Ada peningkatan pengetahuan peserta dalam hal manfaat bawang putih untuk kesehatan, mengenal jenis-jenis bawang putih lokal di Indonesia dan cara bertanam bawang putih dalam polibag.

2. Dalam kegiatan praktek, peserta bisa melakukan tahap-tahap bertanam bawang putih dalam polibag dengan baik.

3. Umbi bawang putih hasil panen para peserta berukuran kecil (diameter umbi 1-2 cm) tidak membentuk siung atau berupa bawang tunggal tetapi mempunyai aroma yang lebih tajam dibanding bawang impor.

\section{UCAPAN TERIMA KASIH}

Kegiatan pengabdian ini terlaksana atas dukungan dana dari Direktorat Riset dan Pengabdian Masyarakat Universitas Tunas Pembangunan Surakarta tahun 2020, untuk itu diucapkan terimakasih yang sebesar-besarnya. 


\section{DAFTAR PUSTAKA}

Anonim, 1993. Bawang Putih Dataran Rendah. Penebar Swadaya. Jakarta.

Badan Pusat Statistik, 2017. Produksi, Luas Panen Dan Produktivitas Sayuran Di Indonesia. http://www.pertanian.go.id

Badan Pusat Statistik, 2017. Ekspor dan Impor. https://www.bps.go.id/all_newtemplate.php

Deresse D., 2010. Antibacterial effect of garlic (Allium sativum) on Staphylococcus aureus: An in vitro study. Asian J Med Sci. October 2010. 